DOI: https://doi.org/10.32836/2521-666X/2020-68-28

УДК 338.001 .36

\author{
Сніщенко Р.Г. \\ кандидат економічних наук, доцент, \\ докторант, \\ Тернопільський національний економічний університет \\ Snishchenko Roman \\ Ternopil National Economic University
}
СОЦАЛЬНА СПРЯМОВАНІСТЬ ПРОЦЕСУ ЗАБЕЗПЕЧЕННЯ ЕКОНОМІЧНОЇ БЕЗПЕКИ ПІДПРИЕМНИЦТВА У ПОСТІНДУСТРІАЛЬНІЙ ПАРАДИГМІ

\title{
SOCIAL ORIENTATION OF THE PROCESS OF ENSURING ECONOMIC SECURITY OF ENTREPRENEURSHIP IN THE POST-INDUSTRIAL PARADIGM
}

Стаття присвячена обгрунтуванню соиіальної спрямованості процесу забезпечення економічної безпеки суб'єктів господарювання у постіндустріальній парадигмі. Об'єктом дослідження є господарські, управлінські і регуляторні проиеси суб'єкта господарської діяльності під час його функиіонування в умовах впливу дестабілізуючих факторів. Предметом дослідження виступають теоретичні засади економічної безпеки суб'єкта господарської діяльності. Визначено, щзо економічна безпека підприємства і сочіальна відповідальність бізнесу є пов'язаними типами сутності проблемної сфери підприємниитвв і впливають на його результативність. Визначені спільні ознаки процесів забезпечення економічної безпеки і сочіальної відповідальності бізнесу. Зазначено, що постіндустріальне суспільство встановлює нові пріоритети для процесу забезпечення економічної безпеки суб'єктів бізнесу.

Ключові слова: безпека економічна, парадигма постіндустріальна, прочес забезпечення, соціальна відповідальність бізнесу, підприємство, суспільство, інтереси. 
Статья посвящена обоснованию соџиальной направленности процесса обеспечения экономической безопасности субъектов хозяйствования в постиндустриальной парадигме. Объектом исследования являются хозяйственные, управленческие и регуляторные проиессы субъекта хозяйственной деятельности при его функиионировании в условиях воздействия дестабилизирующих факторов. Предметом исследования выступают теоретические основы экономической безопасности субъекта хозяйственной деятельности. Определено, что экономическая безопасность предприятия и соииальная ответственность бизнеса являются связанными типами сущности проблемной сферы предпринимательства и влияют на его результативность. Определены общие признаки процессов обеспечения экономической безопасности и соииальной ответственности бизнеса. Отмечено, что постиндустриальное общество устанавливает новые приоритеты для процесса обеспечения экономической безопасности субъектов бизнеса.

Ключевые слова: безопасность экономическая, парадигма постиндустриальная, проиесс обеспечения, соииальная ответственность бизнеса, предприятие, общество, интересь.

In the context of globalization and informatization of world economies, the problems of conducting and protecting business, taking into account the requirements of post-industrial society, which have long gone beyond a purely corporate approach, are becoming especially relevant. The experience of international practice confirms the leading role of the state in the development of corporate social responsibility. Ensuring the economic security of entrepreneurship as one of the main directions of the process of combining business and public interests, requires adaptation to the conditions of the post-industrial economy. The article is devoted to the substantiation of the social orientation of the process of ensuring the economic security of economic entities in the post-industrial paradigm. The object of study are economic, managerial and regulatory processes of the subject of economic activity in its operation under the influence of destabilizing factors. The subject of the study are the theoretical foundations of economic security of the business entity. The article emphasizes that the main principles of social market economy in modern Ukraine should be aimed at subordinating the mercantile, purely economic interests of a highly competitive market to the representative interests of society, and the process of economic security should ensure maximum protection for progressive development of society. It is determined that the economic security of the enterprise and social responsibility of business are related types of the essence of the problem area of entrepreneurship and affect its effectiveness. It is noted that the post-industrial society sets new priorities for the process of ensuring the economic security of business entities. The article argues that at the present stage of economic and social development of Ukraine, the institution of entrepreneurship needs to be significantly developed towards democratization and social orientation of market relations. Economic security of the business sector is an indicator of market reaction to its economic activity. Measures to ensure the economic security of the enterprise, aimed at improving the image of the enterprise in society, have a bilateral positive impact on society and economic activity.

Key words: economic security, post-industrial paradigm, security process, social responsibility of business, enterprise, society, interests.

Постановка проблеми. В умовах глобалізації та інформатизації світових економік особливої актуальності набувають проблеми ведення і захисту бізнесу з урахуванням вимог постіндустріального суспільства, які вже давно вийшли за межі суто корпоративного підходу. Нині питання соціальної спрямованості підприємницької діяльності у високорозвинутих країнах вирішуються на загальнодержавному рівні, створюючи суб'єктам господарювання сприятливі умови для реалізації їх цільового призначення.

Досвід міжнародної практики підтверджує провідну роль держави у розвитку корпоративної соціальної відповідальності. Превалювання принципів кооперації i взаємодопомоги над принципами лобіювання власних інтересів у веденні бізнесу дасть змогу суб'єктам господарювання і суспільству розвиватися синхронно і гармонійно. Забезпечення економічної безпеки підприємництва як один із головних напрямів процесу поєднання бізнесових і суспільних інтересів потребує адаптації до умов постіндустріальної економіки.

Аналіз останніх досліджень і публікацій. Економічна безпека підприємництва є предметом дослідження багатьох українських і закордонних учених. Г.В. Козаченко у [1], О.М. Ляшенко у [2], Н.В. Білошкурська, М.В. Білошкурський у [3] та інші досліджують концептуальні питання сутності, механізму забезпечення та управління економічною безпекою; М.I. Копитко у [4] та інші розглядають іiі галузеві аспекти; С.Б. Довбня, Н.Ю. Гічова у [5] та інші займаються досліджен- ням проблем діагностики рівня економічної безпеки підприємства. Забезпечення соціальної відповідальності бізнесу є предметом дослідження І.П. Булєєва, Н.С. Брюховецької, О.В. Черних [6], Ф. Котлера [7], М. Фрідмана [8], Д.Ю. Нагаївської [9] та інших. Проблеми постіндустріальної економіки та постіндустріального суспільства вивчають Д. Белл [10], Л.В. Лебедева [11] та інші.

Метою статті $\epsilon$ обгрунтування соціальної спрямованості процесу забезпечення економічної безпеки суб'єктів господарювання у постіндустріальній парадигмі.

Об'єктом дослідження є господарські, управлінські і регуляторні процеси суб' єкта господарської діяльності під час його функціонування в умовах впливу дестабілізуючих факторів.

Предметом дослідження виступають теоретичні засади економічної безпеки суб'єкта господарської діяльності.

Виклад основного матеріалу дослідження. У 1991 році Україна зробила вибір не тільки свого державного устрою, а й типу національної економіки, перейшовши з адміністративно-планових на ринкові відносини між регулятором і суб'єктами господарювання. Тому не виникає сумнівів в оптимальності для нашої держави реалізації концепції соціальної економіки ринкового типу.

Термін «соціально-ринкова економіка» був введений у науковий лексикон у 1946 році у книзі «Управ- 


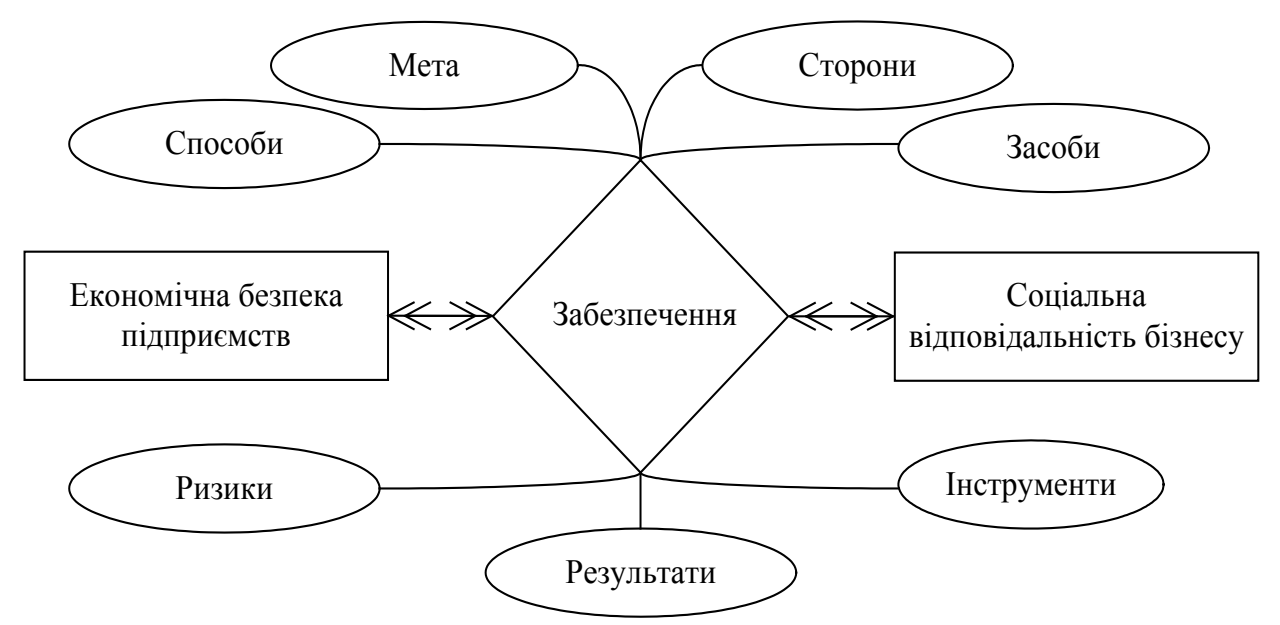

Pис. 1. ER-діаграма зв'язку між економічною безпекою і соціальною відповідальністю бізнесових структур

Джерело: розробка автора

ління економікою і ринкове господарство» [12, с. 76] німецьким економістом, одним із ключових діячів Кельнської школи економістів, професором Альфредом Мюллером Армаком. Він був відповідальним за обгрунтування концепції реформ міністра економіки Людвіга Ерхарда, архітектора «економічного дива» повоєнної Німеччини. Л. Ерхард стверджував, що «ринкова економіка виправдана з економічного та морального погляду тільки доти, доки вона повніше та краще, ніж будь-яка інша форма економіки, забезпечує оптимальне задоволення потреб усього суспільства, коли вона максимальною мірою наділяє номінальні доходи громадян реальною купівельною спроможністю» [13, с. 121].

Стаття 13 Конституції України [14] законодавчо закріплює соціальну спрямованість національної економіки: «Держава забезпечує захист прав усіх суб'єктів права власності і господарювання, соціальну спрямованість економіки».
Головні принципи розбудови соціальної ринкової економіки в сучасній Україні повинні бути спрямовані на підпорядкування меркантильних, суто економічних інтересів висококонкурентного ринку репрезентативним інтересам суспільства. Процес забезпечення економічної безпеки підприємницької діяльності повинен забезпечувати максимальний її захист задля виконання завдань прогресивного розвитку суспільства. Забезпечення економічної безпеки бізнесу полягає насамперед у створенні сприятливих умов реалізації матеріальних і духовних потреб соціуму, який потребує широкого розмаїття якісних товарів і послуг для кожного свого індивіда. Отже, економічна безпека має соціальну спрямованість.

Постіндустріальний розвиток суспільства ставить перед бізнесом нові, більш складні завдання, відмінні від тих завдань, які стояли перед підприємцями в період становлення і розвитку капіталістичних відносин.

Таблиця 1

Спільні ознаки процесів забезпечення економічної безпеки і соціальної відповідальності бізнесу

\begin{tabular}{|c|l|l|}
\hline \multicolumn{1}{|c|}{ Ознака } & \multicolumn{1}{|c|}{ Процес забезпечення економічної безпеки } & \multicolumn{1}{|c|}{$\begin{array}{c}\text { Процес забезпечення соціальної } \\
\text { відповідальності бізнесу }\end{array}$} \\
\hline Мета & $\begin{array}{l}\text { ефективне використання виробничих ресурсів, адаптація до } \\
\text { змін, розроблення та реалізація стратегічних напрямів розви- } \\
\text { тку для забезпечення стійкого функціонування та гармонізації } \\
\text { власних [підприємства] інтересів з інтересами суб'єктів 3о- } \\
\text { внішнього середовища [3, с. 87] }\end{array}$ & $\begin{array}{l}\text { задоволення розумних, здорових по- } \\
\text { них споживачів відповідно до гуман- } \\
\text { нитесів суспільства [9, с. 63] }\end{array}$ \\
\hline $\begin{array}{c}\text { Сторони (учасни- } \\
\text { ки) процесу }\end{array}$ & власники, персонал, клієнти, партнери, конкуренти & $\begin{array}{l}\text { власники, персонал, клієнти, партнери, } \\
\text { інші члени суспільства }\end{array}$ \\
\hline $\begin{array}{c}\text { Засоби досягнення } \\
\text { мети }\end{array}$ & організаційні, правові, морально-етичні & морально-етичні \\
\hline Інструменти & примус, спонукання & спонукання \\
\hline Ризики (загрози) & усі види ризиків (загроз) & нефінансові ризики (загрози) \\
\hline Способи & $\begin{array}{l}\text { посилення сприятливих факторів зовнішнього і внутрішнього } \\
\text { впливу, мінімізація або ліквідація загроз }\end{array}$ & $\begin{array}{l}\text { посилення сприятливих факторів } \\
\text { зовнішнього і внутрішнього впливу }\end{array}$ \\
\hline \multicolumn{2}{|c|}{ Результат } & $\begin{array}{l}\text { підвищення ефективності виробничих процесів та якості продукції і послуг; } \\
\text { посилення мотивації та підвищення продуктивності праці робітників; } \\
\text { поліпшення ділової репутації компанії; зменшення ризиків }\end{array}$ \\
\hline
\end{tabular}

Джерело: згруповано автором 


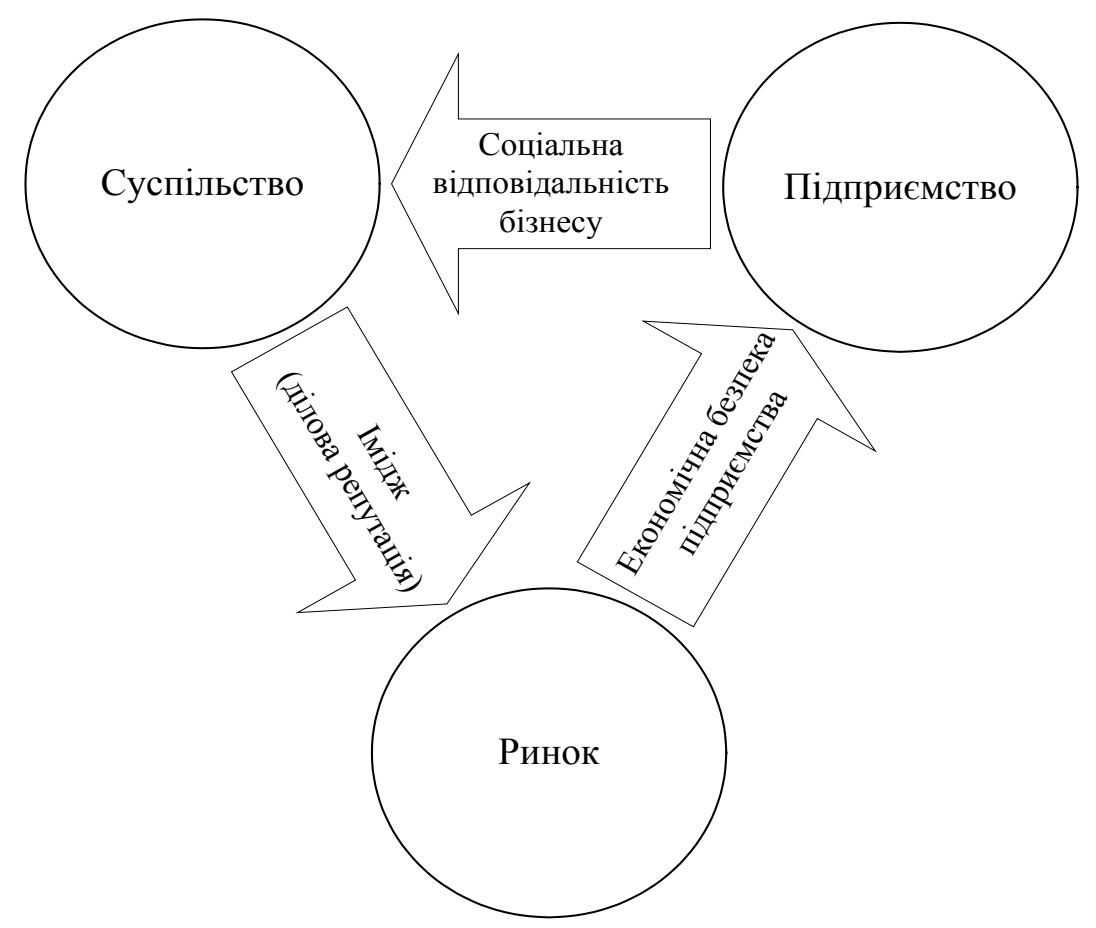

Рис. 2. Місце економічної безпеки у зв'язку підприсмства з суспільством

Джерело: розробка автора

Інститут ринкових відносин, поступово об'єднуючись 3 інститутом соціальних практик, змінює суспільні погляди на підприємництво і розвивається сам. Соціальна спрямованість бізнесової діяльності, яка була характерною рисою лише розвинутих економік, тепер стає популярною і в країнах, де підприємництво тільки набирає ознаки цивілізованості.

Ідею про соціальну відповідальність бізнесових структур за результати своєї діяльності висловив Генеральний Секретар Організації Об’єднаних Націй Кофі Аннан, який на засіданні Всесвітнього економічного форуму 31 січня 1999 року звернувся до бізнес-лідерів із закликом приєднатися до міжнародної ініціативи - Глобального Договору. Ця ініціатива повинна об’єднати компанії, агенції ООН, а також трудові та громадські організації з метою підтримки світових екологічних і соціальних принципів. Нині понад 3800 компаній з усіх регіонів світу, включно $з$ міжнародними трудовими та громадськими організаціями, беруть участь у Глобальному Договорі, працюючи над розповсюдженням десяти універсальних принципів у сфері прав людини, праці, екології та протидії корупції [15].

Економічна безпека підприємства і соціальна відповідальність бізнесу є пов'язаними типами сутності проблемної сфери підприємництва i, доповнюючи одна одну, впливають на його результативність.

На рис. 1 зв'язок між економічною безпекою і соціальною відповідальністю бізнесових структур зображений у вигляді ER-діаграми - способу представлення проблемної сфери на інфологічному рівні, запропонованого П. Пін-Шен Ченом у 1976 році [16].
Як видно з рис. 1, типи сутностей «економічна безпека підприємств» і «соціальна відповідальність бізнесу» мають спільні атрибути-ознаки через зв'язок «забезпечення» типу М:М. Це пояснюється тим, що досягнення економічної безпеки, будучи забезпечувальним процесом, сприяє виконанню підприємством його розширеного завдання соціальної відповідальності. Кожен атрибут-ознака за необхідності декомпозиції завдання дослідження може бути представлений у вигляді окремого типу сутності. У цьому разі досить їх порівняння (табл. 1).

Можна відповідально стверджувати, що найкращим показником високого рівня економічної безпеки суб'єкта господарювання є його успішна бізнесова діяльність. Успішна бізнесова діяльність неможлива без підтримки соціуму, з яким у підприємства є зворотний зв'язок (рис. 2).

3 рис. 2 видно, що економічна безпека підприємницького сектору є індикатором реакції ринку на його господарську діяльність. Суспільство, реагуючи на заходи підприємства з урахування потреб соціуму, формує для себе його імідж і шляхом підвищення попиту або пропозиції впливає на його ринкову позицію. Зміна кон'юнктури ринку впливає на економічну безпеку суб'єкта господарської діяльності, викликаючи необхідність проведення заходів соціальної спрямованості.

У 1959 році професор Гарвардського університету Д. Белл уперше використав поняття постіндустріального суспільства для позначення соціуму, в якому промисловий сектор вже не відіграє вирішальної ролі через 
технологічний прогрес, а основною продуктивною силою стає людський розум і досвід. У своїй праці «Прийдешне постіндустріальне суспільство» [10, с. 171]. Д. Белл зазначає: «Постіндустріальне суспільство засноване на послугах, тому воно - гра між людьми. Головне значення мають уже не мускульна сила і не енергія, а інформація. Основною діючою особою стає професіонал, тому що його досвід і знання дозволяють йому відповідати усім вимогам, яких вимагає постіндустріальне суспільство. Якщо індустріальне суспільство визначається через кількість товарів, що позначає рівень життя, то постіндустріальне суспільство визначається рівнем життя, вимірюється послугами - охороною здоров'я, відпочинком і культурою» [1, с. 171].

Зміна соціально-технологічного аспекту суспільства спричинила формування нової технологічної системи підприємництва, яка прийшла на зміну індустріальному типу господарювання. Це встановлює нові пріоритети для процесу забезпечення економічної безпеки суб' єктів бізнесу.

Україна, як і всі учасниці колишнього СРСР, має дуже короткий досвід самостійного існування і не встигла придбати ознаки розвинутої постіндустріальної держави. На сучасному етапі основними перешкодами для соціальної спрямованості бізнесової діяльності в Україні $є$ інституціональні деформації iii економіки: тіньова парадержава, рейдерство, непродуктивний відплив капіталу, корупція тощо. 3.С. Варналій стверджує, що «саме ці форми інституціональних деформацій є найбільшими за обсягами, соціально-економічними наслідками та реальними загрозами фінансовій безпеці України» [17, с. 7].
Українська дослідниця Л.В. Лебедєва зазначає: «Перехід від хижацького суспільства індустріальної економіки до постіндустріального, відбувається у самій людині, у ставленні іiї до інших, але цій зміні повинна передувати значна робота державного апарату з налагодження системи оплати найманої праці, встановлення справді демократичного державного устрою. Цей стан задоволеності, «ситості» людини може бути досягнутим лише тоді, коли 60-70\% у вартості виготовленої продукції буде становити заробітна плата працівників, як це зараз є у країнах постіндустріальної економіки» [11, с. 32].

Набутий за роки незалежності вітчизняний досвід забезпечення економічної безпеки підприємницького сектору й аналогічний досвід розвинутих зарубіжних країн свідчить, що на перших етапах становлення цівілізованих економічних відносин між бізнесом і суспільством регуляторний вплив держави обов'язковий. Він повинен закласти міцний правовий фундамент цих відносин на основі врахування інтересів зацікавлених сторін і визначити державні і суспільні інститути контролю і регулювання господарської діяльності.

Висновки. Підсумовуючи вищенаведене, можна зазначити, що на сучасному етапі економічного і соціального розвитку України інститут підприємництва потребує суттєвої розбудови в бік демократизації і суспільного спрямування ринкових відносин. Економічна безпека підприємницького сектору є індикатором реакції ринку на його господарську діяльність. Заходи із забезпечення економічної безпеки підприємства, спрямовані на підвищення іміджу підприємства в суспільстві, мають двобічний позитивний вплив і на соціум, i на господарську діяльність.

\section{Список літератури:}

1. Козаченко Г.В., Пономарьов В.П., Ляшенко О.М. Економічна безпека підприємства: сутність та механізм забезпечення : монографія. Київ : Лібра, 2003. 280 с.

2. Ляшенко О.М. Концептуалізація управління економічною безпекою підприємства : монографія. Луганськ : СНУ ім. В.Даля, 2011. 400 с.

3. Білошкурська Н.В., Білошкурський М.В. Теоретичні аспекти економічної безпеки підприємств. Сталий розвиток економіки. 2013. № 2. C. 85-89. URL: https://www.uniep.km.ua/pdf/_2_2013.pdf (дата звернення: 05.03.2020 р.).

4. Економічна безпека підприємств з виробництва транспортних засобів : монографія / наук. ред. В.Г. Алькема. Львів : Ліга-Прес, 2015. 555 с.

5. Довбня С.Б., Гічова Н.Ю. Діагностика рівня економічної безпеки підприємства. Фінанси Украӥни. 2008. № 4. С. 88-97.

6. Булеев И.П., Брюховецкая Н.Е., Черных Е.В. Социальная ответственность бизнеса: теория и практика : монография. Донецк : ДонНТУ, 2008. 136 с.

7. Котлер Ф. Корпоративна соціальна відповідальність. Як зробити якомога більше добра для вашої компанії та суспільства / пер. 3 англ. С. Яринич. Київ : Стандарт, 2005. 302 с.

8. Friedman M. The Social Responsibility of Business is to increase its Profit. New York Times Magazine. 1970. September, № 13. Р. 122-126. (дата звернення: 05.03.2020 р.).

9. Нагаївська Д. Ю. Забезпечення соціальної відповідальності бізнесу на ринку продовольчих товарів : дис. ... канд. екон. наук : 08.00.07. Харків, 2018. 285 с.

10. Белл Д. Грядущее постиндустриальное общество. Опыт социального прогнозирования. Москва : Academia, 1999. 773 с.

11. Лебедева Л.В. Постіндустріальна економіка та постіндустріальне суспільство: критерії розмежування та існуючі моделі. Вісник Чернівецького торговельно-економічного інституту. Економічні науки. 2010. № 4. С. 29 -36.

12. Мюллер-Армак А. Принципы социального рыночного хозяйства. Социальное рыночное хозяйство: концепция, практический опыт и перспективы применения в России / под ред. Р.М. Нуреева. Москва : Издательский дом, 2007. 320 c. 
13. Эрхард Людвиг Вильгельм. Благосостояние для всех. Москва : Дело, 2001. 352 с.

14. Конституція України : Закон України від 28.06.1996р. №254к/96-ВР / Верховна Рада України. Відомості Верховної Ради Украӥни (ВВР), 1996, № 30, Сm. 141. URL: https://zakon.rada.gov.ua/laws/show/254к/96-вр (дата звернення: 05.03.2020 р.).

15. Про Глобальний Договір ООН. Українська мережа Глобального договору OOH. URL: http://www.globalcompact.org.ua/ua/about/what (дата звернення: 05.03.2020 p.).

16. Peter Pin-Shan Chen. The Entity-Relationship Model - Toward a Unified View of Data. ACM Transactions on Database Systems (TODS). Сб. - Нью-Йорк : АСМ, 1976. Vol. 1. Р. 9-36.

17. Варналій 3.С. Основні форми та шляхи протидії інституціональним деформаціям фінансової безпеки України. Фінансова безпека в системі забезпечення національних інтересів: проблеми та перспективи: матеріали Міжнар. наук.-практ. конф., м. Полтава, 18-19 квітня 2012 р. Полтава, 2012. С. 13-16.

\section{References:}

1. Kozachenko H.V., Ponomarev V.P., Lyashenko O.M. (2003) Ekonomichna bezpeka pidpryyemstva: sutnist' ta mekhanizm zabezpechennya: monohrafiya [Economic security of the enterprise: essence and mechanism of maintenance: monograph]. Kyiv: Libra (in Ukrainian).

2. Lyashenko O.M. (2011). Kontseptualizatsiya upravlinnya ekonomichnoyu bezpekoyu pidpryyemstva: monohrafiya [Conceptualization of management of economic security of the enterprise: monograph]. Luhansk: Volodymyr Dahl East Ukrainian National University (in Ukrainian)

3. Biloshkurska NV, Biloshkursky MV (2013) Teoretychni aspekty ekonomichnoyi bezpeky pidpryyemstv. [Theoretical aspects of economic security of enterprises]. Stalyy rozvytok ekonomiky [Sustainable economic development]. (electronic journal), no. 2, pp. 85-89. Available at: https://www.uniep.km.ua/pdf/_2_2013.pdf (accessed 05.03.2020).

4. Kopytko M.I. (2015) Ekonomichna bezpeka pidpryyemstv z vyrobnytstva transportnykh zasobiv: monohrafiya [Economic security of enterprises for the production of vehicles: monograph]. Lviv: Liga-Press (in Ukrainian).

5. Dovbnya S., Hichova N. (2008) Diahnostyka rivnya ekonomichnoyi bezpeky pidpryyemstva. [Diagnosis of the level of economic security of the enterprise. Finance of Ukraine]. Finansy Ukrainy, no 4, pp. 88-97.

6. Buleyev I.P., Bryukhovetskaya N.Ye, Chernykh Ye.V. (2008) Sotsial'naya otvetstvennost' biznesa: teoriya i praktika: monografiya [Social responsibility of business: theory and practice: monograph]. Donetsk: DonNTU (in Ukrainian).

7. Kotler F. (2005). Korporatyvna sotsial'na vidpovidal'nist'. Yak zrobyty yakomoha bil'she dobra dlya vashoyi kompaniyi ta suspil'stva [Corporate social responsibility. How to do as much good as possible for your company and society] Kyiv: Standart (in Ukrainian).

8. Friedman M. (1999) The Social Responsibility of Business is to increase its Profit // New York Times Magazine. 1970. September, no. 13, pp. 122-126.

9. Nahayivs'ka D. YU. (2018) Zabezpechennya sotsial'noyi vidpovidal'nosti biznesu na rynku prodovol'chykh tovariv [Ensuring social responsibility of business in the market of food products] (PhD Thesis), Kharkiv. Simon Kuznets Kharkiv National University of Economics (in Ukrainian).

10. Bell D. (1999) Gryadushcheye postindustrial'noye obshchestvo. Opyt sotsial'nogo prognozirovaniya [Bell D. The Coming Post-Industrial Society. Social Forecasting Experience]. Moscow: Academia (in Russian).

11. Lebedeva L.V. (2010) Postindustrial'na ekonomika ta postindustrial'ne suspil'stvo: kryteriyi rozmezhuvannya ta isnuyuchi modeli.[Post-industrial economy and post-industrial society: differentiation criteria and existing models]. Bulletin of the Chernivtsi Trade and Economic Institute. Economic sciences, vol. 4, pp. 29-36.

12. Myuller-Armak A. (2007) Printsipy sotsial'nogo rynochnogo khozyaystva. Sotsial'noye rynochnoye khozyaystvo: kontseptsiya, prakticheskiy opyt i perspektivy primeneniya v Rossii [Principles of social market economy. Social market economy: concept, practical experience and prospects of application in Russia]. Moscow: Publishing House (in Russian).

13. Erhard Ludwig Wilhelm (2001). Blagosostoyaniye dlya vsekh [Well-being for all] Moscow: Delo (in Russian).

14. Konstytutsiya Ukrayiny. Vidomosti Verkhovnoyi Rady Ukrayiny (VVR), 1996, № 30, st. 141. [Constitution of Ukraine. Information of the Verkhovna Rada of Ukraine (VVR), 1996, № 30, Art. 141.]. Verkhovna Rada of Ukraine. Available at: https://zakon.rada.gov.ua/laws. (accessed 05.03.2020).

15. Pro Hlobal'nyy Dohovir OON. [On the UN Global Compact]. Ukrainian network of the UN Global Compact. Available at: http://www.globalcompact.org.ua/ua/about/what (accessed 05.03.2020).

16. Peter Pin-Shan Chen (1976) The Entity-Relationship Model - Toward a Unified View of Data // ACM Transactions on Database Systems (TODS). New York: ACM, vol. 1, p. 9-36.

17. Varnaliy Z.S. (2012) Osnovni formy ta shlyakhy protydiyi instytutsional'nym deformatsiyam finansovoyi bezpeky Ukrayiny. [Basic forms and ways of counteraction to institutional deformations of financial security of Ukraine] Proceedings of the Finansova bezpeka $v$ systemi zabezpechennya natsional'nykh interesiv: problemy ta perspektyvy. (Poltava, Ukraine, April 18-19, 2012) Poltava: PoltNTU pp. 13-16. 